\title{
CADETS IN PORTUGUESE MILITARY ACADEMIES A sociological portrait
}

\author{
Helena Carreiras \\ Instituto Universitário de Lisboa (ISCTE-IUL), Centro de Investigação e Estudos de Sociologia \\ (Cies_Iscte), Lisboa, Portugal \\ Fernando Bessa \\ Military University Institute, Centre for Research in Security and Defence (CISD), Lisboa, \\ Portugal \\ Patrícia Ávila \\ Instituto Universitário de Lisboa (ISCTE-IUL), Centro de Investigação e Estudos de Sociologia \\ (Cies_Iscte), Lisboa, Portugal \\ Luís Malheiro \\ Military University Institute, Centre for Research in Security and Defence (CISD), Lisboa, \\ Portugal
}

\begin{abstract}
The aim of this article is to revisit the question of the social origins of the armed forces officer corps, using data drawn from a survey to all cadets following military training at the three Portuguese service academies in 2016. It puts forward the question of whether the sociological characteristics of the future military elite reveal a pattern of convergence with society or depart from it, in terms of geographical origins, gender and social origins. The article offers a sociological portrait of the cadets and compares it with previous studies, identifying trends of change and continuity. The results show that there is a diversified and convergent recruitment pattern: cadets are coming from a greater variety of regions in the country than in the past; there is a still an asymmetric but improving gender balance; self-recruitment patterns are rather stable, and there is a segmented social origin pointing to the dominance of the more qualified and affluent social classes. In the conclusion questions are raised regarding future civil-military convergence patterns as well as possible growing differences between ranks.
\end{abstract}

Keywords: military cadets, officer corps, social origins, civil-military relations.

Cadetes nas academias militares portuguesas: um retrato sociológico

Resumo O objetivo do presente artigo é revisitar a questão das origens sociais do corpo de oficiais das Forças Armadas, utilizando dados de um inquérito aplicado a todos os cadetes que frequentavam os cursos das escolas superiores militares, em 2016. Coloca-se a questão de saber se as características sociológicas das futuras elites militares revelam um padrão de convergência com a sociedade ou se dela se afastam, em termos de origens geográficas, género e origens sociais. O artigo apresenta um retrato sociológico dos cadetes e compara-o com estudos anteriores, identificando tendências de mudança e continuidade. Os resultados demonstram que existe diversidade e convergência no padrão de recrutamento: os cadetes são oriundos de uma maior variedade de regiões do país relativamente ao passado; persistem assimetrias de género, mas que têm vindo a diluir-se; os padrões de autorrecrutamento são estáveis; e subsiste uma segmentação na origem social que aponta para a dominância das classes sociais mais qualificadas e com maiores recursos. Na conclusão são levantadas questões sobre os padrões de convergência civil-militar, bem como sobre o possível aumento das diferenças entre categorias no interior das forças militares.

Palavras-chave: cadetes militares, corpo de oficiais, origens sociais, relações civis-militares.

Cadets des academies militaires portugaises: un portrait sociologique

Résumé L'objectif de cet article est de réexaminer la question des origines sociales du corps des officiers des forces armées, en utilisant les données d'une enquête auprès de tous les cadets suivant une formation militaire dans les trois académies de service portugaises en 2016. La question se pose de savoir si les caractéristiques sociologiques des futures élites militaires révèlent un modèle de convergence avec la société, ou si elles s'en 
écartent en termes d'origines géographiques, de genre et d'origine sociale. L'article présente un portrait sociologique des cadets et le compare avec des études antérieures, identifiant des tendances de changement et de continuité. Les résultats montrent qu'il existe une diversité et une convergence dans la structure du recrutement: les cadets proviennent d'une plus grande variété de régions du pays que par le passé; les asymétries entre les sexes persistent mais ont été diluées; les standards d'auto-recrutement sont stables; et il existe une segmentation de l'origine sociale qui indique la domination des classes sociales les plus qualifiées et mieux pourvues de ressources. Dans la conclusion, des questions sont soulevées sur les modèles de convergence civilo-militaire, ainsi que l'accroissement possible des différences entre les catégories au sein de l'armée.

Mots-clés: cadets militaires, corps d'officiers, origines sociales, relations civilo-militaires.

Cadetes en las academias militares portuguesas: un retrato sociológico

Resumen El objetivo del presente artículo es el de revisar la cuestión de los orígenes sociales del cuerpo de oficiales de las Fuerzas Armadas, utilizando datos de una encuesta aplicada a todos los cadetes que frecuentaban los cursos de las escuelas superiores militares, en 2016. Se plantea la cuestión de si las características sociológicas de las futuras élites militares revelan un patrón de convergencia con la sociedad o si de ella se alejan, en términos de orígenes geográficos, género y orígenes sociales. El artículo presenta un retrato sociológico de los cadetes y lo compara con estudios anteriores, identificando tendencias de cambio y continuidad. Los resultados demuestran que existe diversidad y convergencia en el patrón de reclutamiento: los cadetes provienen de una mayor variedad de regiones del país con respecto al pasado; persisten asimetrías de género pero que se han diluido; los patrones de autorecrutamiento son estables; y subsiste una segmentación en el origen social que apunta a la dominación de las clases sociales más cualificadas y con mayores recursos. En la conclusión se plantean cuestiones sobre los patrones de convergencia civil-militar, así como sobre el posible aumento de las diferencias entre categorías dentro de las fuerzas militares.

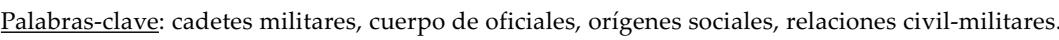

\section{Introduction}

The question of the social characteristics of the military, especially those of its officer corps, has been a major issue in the sociological study of the armed forces, ever since it was developed in the US in the early 1950's, and at least until the late 1980's. Different studies have relied on the concept of social origins to explain behavioral and ideological patterns, namely relating it to the classical problem of the political role of the military and its propensity to intervene in politics. Others, on the contrary, questioned the effect of recruitment patterns on ideology, underlining the intense socialization process in military academies as the main explanatory variable for officers' behavior and attitudes. This debate has been taking place against a common concern, which has also been the central problem in the sociology of the military: the relationship between the armed forces and society and the changing trends towards convergence or divergence between them. As major transformations in the structure of military organizations and civil-military relations of advanced democracies highlighted a pattern of growing convergence between military and society, the concern over structural factors such as social origins seemed to fade away, but only to be replaced, some decades later, by a renewed attention to a potential civil-military values gap (Caforio, 2007a; Feaver, 2001). 
At a moment when heightened security concerns fuel new discussions over the role of the military and its interface with other political and security actors, there is room for revisiting the debate and looking, again, at a broad range of sociological characteristics of the future military elites. This is the goal of the present article, which focuses on the sociological characteristics of the cadets. The central research question is the following: to what extent does the most powerful group in the organization - the future officer corps - reflect the structural characteristics of the larger society? Is it drawn from particular groups or territories, or, on the contrary, mirrors social diversity? Drawing on empirical data from the project "Cadets in Portuguese Military Academies: Social Characteristics, Institutional Representations and Professional Orientations" developed at the Military University Institute (IUM), the article examines a variety of sociological features of the cadets of all three military academies and schools (Military Academy, Naval School and Air Force Academy).

The project was based on a partnership between the Military University Institute (Instituto Universitário Militar - IUM), the national gendarmerie, National Republican Guard (Guarda Nacional Republicana - GNR), and the Centre for Research and Studies in Sociology (Cies_Iscte) of the Iscte - Instituto Universitário de Lisboa, and relies on an online survey of the total universe of cadets, which was conducted in 2016.

\section{Armed forces and society: analytical perspectives on the officer corps}

The question of the sociological characteristics of the officer corps and its proximity or distance from societal patterns has been a permanent constituent of the social scientific study of the military (Abrahamsson, 1972; Finer, 1962; Huntington, 1957; Janowitz, 1960). After the end of World War II, and in the context of major transformations regarding the role of the armed forces, military sociologists focused their analyses on the degree of convergence or divergence of the armed forces towards civilian organizations and societal values, and questions related to professionalism have acquired major importance. While some focused on the divergence factors, underling the homogeneity and the relative autonomy of the officer corps as a distinctive feature of military institutions (Huntington, 1957), others pointed to the development of a converging tendency between civilian and military organizations (Janowitz, 1960). In The Soldier and the State, Huntington identified the development of military "professionalism" as the distinctive element of the military profession compared with civilian occupations, while at the same time distinguishing the present military from its predecessors. Based on expertise, responsibility and corporateness, professionalism was seen as a specific type of vocation shared by career officers who would therefore assure the specificity of the military organization. An alternative perspective developed from Morris Janowitz' classical work which signaled a trend towards civilianization, stressing the growing convergence between the military and civil society (Janowitz, 1960). According to 
this perspective, technological developments occasioned institutional fragmentation and a growing dependence of military organizations on non-military expertise and technologies, thereby narrowing differences between the two sectors. As a result of the rationalization process, affecting both civilian and military institutions, bureaucratic structures lose weight, combatants become a minority, and leadership styles become less authoritarian. In addition, the author believes that such a convergence partially dilutes the sources of potential ideological conflict between civilian and military elites. Janowitz's civilianization thesis opposed, albeit only implicitly, Huntington's hypothesis, which assumed the need for a certain military isolation from society as a basic condition to ensure organizational efficiency and political neutrality. Despite this difference in emphasis - which continued to characterize later work in this area - , most of the subsequent proposals reveal some conceptual continuity. While recognizing the structural distinctiveness of military institutions - that is, the ever-present probability of combat and the monopoly of organized violence - most of them pointed to increasing commonalities between military and other bureaucratic organizations.

Janowitz inaugurated a paradigm that became dominant, giving rise to a variety of perspectives within the sociological study of military institutions. The common core of all the research aiming at explaining change lies in a generalized perception of the decline in relevance, legitimacy and prestige accorded by contemporary society to the military profession, the dilution of its specific contents, and a shift in the value orientation of military professionals. This was also the starting point for Moskos' analysis of change within the American military. In order to overcome strict theoretical and methodological oppositions around micro-macro or action-structure polarities, he proposed a model highlighting the ever-changing interface between armed forces and society, which came to be known as the I/O thesis (Moskos, 1977, 1985, 1986; Moskos and Wood, 1988). This has become one of the most influential models in military sociology. In this model, a set of polarized empirical indicators is identified in a continuum ranging from a military organization that is highly divergent from civilian society to one which is highly convergent with civilian structures. Two ideal-type models are conceptualized: an institutional or divergent model, legitimated in terms of norms and traditional values, where the members of the institution are seen as following a "vocation", relying on symbolic rewards and sharing "a purpose transcending individual self-interest in favor of a presumed higher good" (Moskos, 1986: 378); and an occupational or convergent model, close to the dominant market rationality of civilian society, where motivations to join or remain in the military are of an extrinsic material and instrumental nature.

In this sense, the military organization could become plural or segmented: while some sectors would remain distinctively military and divergent from civil society (such as the combat units), others, particularly in the more administrative or technical areas, would progressively resemble an occupation.

Debates that ensued from the I/O thesis have, for the most part, left the question of the social origins of the officer corps unscrutinized. However, some attempts at theorizing social origins within civil-military relations theory or at 
empirically examining the topic have been present in the sociology of the military during the past two decades.

From a theoretical point of view, Rebecca Schiff has put forward a "concordance theory" of civil-military relations, which can be seen as a particular development of the convergence perspective. She maintains that the military, the political elites and the citizenry should aim for a cooperative relationship that might involve separation of the military and civilian spheres, but does not require it. In this perspective, the specific type of civil-military relations adopted is less important than the ability of those partners to agree on four indicators: social composition of the officer corps, political decision-making process, recruitment method, and military style. Here, the social composition of the officer corps is seen as a primary indicator of concordance: "In democratic societies the officer corps usually represents the various constituencies of the nation," but "broad representation is not a requisite condition for concordance, since it is conceivable that the society and the military could agree on a less broadly representative corps" (Schiff, 2009: 45).

On the empirical front, Caforio has led some of the most significant studies focusing on cadets and professional socialization in military academies. A first comparative international study, published in 1998, looked at the role of military educational institutions as secondary socialization agencies. The study showed that in the European countries examined, cadets came prevalently from the middle class, with more lower-class origins in the ex-communist countries and more accentuated upper-class recruitment for the remaining countries, namely France and Holland. However, there was also a gradual tendency for the situations to converge: recruitment in the Eastern European countries becoming more elitist and a greater democratization in Western Europe. The study also pointed to a decrease in self-recruitment: "The percentage of cadets who are sons of military men, still $20 \%$ of the total on average, tends to diminish, and this is a phenomenon that could contribute to greater convergence (in the Janowitzian sense) of military professionals with the parent society." (Caforio, 1998: 156).

Additional survey research conducted by different national teams under Caforio's coordination between 1991 and 2004 has confirmed the idea put forward by Harries-Jenkins (1990: 119) of a proletarianisation of the military profession. From Caforio's data sets such a hypothesis emerged as more than a statistical curiosity: "both the career choices and the cultural model of the officer [...] show that they are influenced by the individual's social origin" (Caforio 2007b: 230). The research also confirmed the presence of significant self-recruitment - from $12 \%$ to $30 \%$ - although with a slight downward trend throughout the period (Caforio, 2007b: 230). Such a trend is different from the one observed in other parts of the world. Research on the Brazilian case, for instance, has shown a strong and increasing tendency to self-recruitment throughout the second half of the $20^{\text {th }}$ century, with around half of the cadets in the Army academy coming from military families by the end of the 1980's (Castro, 1994: 225). 


\section{Sociological portrait of Portuguese military cadets}

The military have not been extensively or systematically studied in Portugal. The same applies to the officer corps, even though some groundbreaking research has been conducted at different points in time. The first study focusing on the social origins of the officer corps, including all branches of the armed forces, was conducted by Carrilho in the early 1980's (Carrilho, 1982). Drawing on administrative data from individual files of cadets who finished their education in the service academies between 1910 and 1980, Carrilho was able to provide the first mapping of the sociological characteristics of the Portuguese officer corps throughout the twentieth century. Her study was particularly relevant at a time where the hypothesis of a direct relationship between the social origin of cadets and the political role of the military in the democratic coup of 1974 was spreading.

There was the conviction that under the pressure of the Colonial War's need for officers, the opening of military schools to students coming from poorer or working class sectors of the population had fostered change in the social composition of the officer corps (which was thought to be mainly recruited from dominantly rural, aristocratic or bourgeois backgrounds), and that this had prompted the development of revolutionary ideas that eventually led to the coup of $25^{\text {th }}$ April 1974. Against this dominant thesis, Carrilho showed that throughout the twentieth century the more affluent classes did not show great interest in the armed forces; the percentage of self-recruitment had fallen significantly and a large percentage of cadets were already coming from urban areas and from the lower strata of the bourgeoisie and the state administration sector. Even if there was a slight increase of working-class origins of those in the ranks of major and captain in 1974, only $12 \%$ of the cadets had proletarian origins, which, even overlooking the deterministic and mechanistic character of the established connection, was hardly a significant basis to infer possible ideological contamination. Carrilho's work was later replicated in 1994 confirming the increasingly diversified social origins of cadets and the overall "democratization" of the officer corps (Carrilho, 1994). In 2011, another study on the Portuguese Armed Forces after the Cold War directed by Carreiras (Carreiras et al. 2011) updated the social origins of cadets for the period 1989-2010. This study pointed to the consolidation of social origins' diversity, confirming the weight of the middle class, namely executive employee positions in the cadets' family background.

Despite their relevance, all these studies were based on secondary documentary evidence from administrative files, which raised important methodological questions regarding the limited category range for different variables, the difficult comparability and the often irregular record and storage of information throughout time. More recently, Bessa (2015) conducted an international comparative sociological survey of military academy cadets from the Guarda Nacional Republicana (Portugal), the Koninklijke Marechaussee (The Netherlands), Guardia Civil (Spain) and Gendarmerie Française (France), but in this case, data regarded only this specific group and not the other branches' study programmes.

The present article constitutes thus an attempt at extending previous research efforts, identifying the overall characteristics of the future officer corps of the Portuguese 
Armed Forces and monitor change over time. While the project has a broad scope that includes examining the recruitment framework of academies, drawing the sociological portraits of the cadets, and addressing different dimensions of institutional representations and professional orientations, the present article focuses exclusively on social demographics, exploring the topic of the social origins of the officer corps.

\section{Methodology}

This research relied on a quantitative methodological design, based on an online survey to all military cadets in the three Portuguese service academies (Military Academy, Naval School and Air Force Academy), conducted in 2016.

Besides some additional training programmes, the service academies, all located in the Lisbon area, provide the compulsory training for officers of the different combat arms and services of the Portuguese Armed Forces. Integrated master programmes at the Military Academy constitute the basic education to access the officers' corps of the permanent structure of the Army and the National Republican Guard (GNR). These include the different arms and services gathered in four scientific areas: Military Sciences, Administration and Management, Engineering, and Health. There are three programs for access to the combat arms - Infantry, Artillery, and Cavalry - and three others in Military Administration, Engineering and Medicine (the last two in cooperation with civilian universities). The Academy also trains the future officers of the Guarda Nacional Republicana, offering an integrated master program in Military Sciences-Security.

The Air Force Academy and Navy School provide integrated master programs in the same four broad scientific areas: Military Sciences, Administration, Engineering and Health. The Air Force Academy offers integrated master programs in military aeronautics (Pilot-aviator, Aeronautical Administration, Electrical Engineering, Airfield Engineering and Aeronautical Engineering) and in Medicine (in cooperation with civilian universities). The Navy School offers integrated master programs in naval matters with the following specifications: Navy Specialty, Naval Administration, Marines, Naval Engineering (mechanics), Naval Engineering (weapons and electronics) and Naval Medicine (in cooperation with the University of Lisbon).

The preparation of the survey relied on the analytical dimensions and specific goals defined for the project. The questions covered five central dimensions: (1) social demographics (age, sex, marital status, place of birth/residence, educational background, familial links to the military and police professions, social origin of cadets); (2) reasons/motivations to decide to choose a military/police profession; (3) institutional representations (opinion about the children of military/police, expectations about the armed forces and security forces/GNR, experiences and everyday representations as citizens, satisfaction with major social issues, national and European identification, perceptions of personal life, and self-assessment); (4) professional orientations of cadets of military schools (I/O orientations and professional guidance); and (5) human values in general. This article examines results from the first dimension, namely selected indicators of social demographics: geographical origins, gender and social origins. 


\begin{tabular}{|c|c|c|c|}
\hline & Total of cadets & Cadets who participated & Response rate \\
\hline Navy School & 217 & 192 & 88.48 \\
\hline Military Academy - Army & 296 & 279 & 94.26 \\
\hline Military Academy - GNR & 167 & 166 & 99.40 \\
\hline Air Force Academy & 140 & 140 & 100.00 \\
\hline Total & 820 & 777 & 94.80 \\
\hline
\end{tabular}

Source: Project "Cadets in Portuguese military academies in Portugal, 2016."

The planning of the survey contents took into account the existence of similar surveys, conducted both nationally and internationally. ${ }^{1}$ Despite the different timeframe and context, some questions were replicated in order to allow possible comparisons. It was built on the "Surveymonkey" platform and pre-tested in November 2015, after which some minor corrections were introduced. Using an online secure link, an e-mail was then sent to each of the cadets who could fill in the survey anonymously. This procedure made it impossible to resend the survey and was later on evaluated as highly effective. The survey was then conducted between January and June 2016.

An explicit agreement from the chain of command at the Military University Institute - the umbrella organization for the service academies -, and on the part of all three academy commanders, made it possible to survey all cadets, and not just a representative sample (table 1).

Table 1 shows the universe and response rate by academy, which can be considered very high, since 777 cadets completed the survey, making up for almost $94.5 \%$ of the universe. The remaining $5.2 \%$ who were unable to fill in the survey were rather evenly distributed along the different study years and schools, which means that their absence does not affect the reliability of the global results.

All data analysis was performed using the SPSS software.

\section{Socio-demographic profile of cadets}

A first group of questions in the survey focused on the demographics of the cadets in terms of geographical origin, gender, as well as social origin, including analysis of reproduction patterns, that is, family antecedents in the armed forces, Police forces or security services. ${ }^{2}$

1 The survey replicated questions used in questionnaires that tested the I/O dimensions (Moskos and Wood, 1988: 293-295), in the European Social Survey concerning human values and from the project "Portuguese Armed Forces after the Cold War" developed by the Centre for Research and Studies in Sociology (Cies_Iscte) (Carreiras et al., 2011).

2 In Portugal the internal security functions are performed by two main police forces (Guarda Nacional Republicana and Polícia de Segurança Pública) and three security services (Judiciary Police; Foreign and Boarders Service and Security Information Service (art. $.255^{\circ}$, n.․ 2, Law n.. $53 / 2008$ - Internal Security Law). According to the n. 3 of the same law the National Maritime Authority and the System of the Aeronautical Authority also performed security functions. 


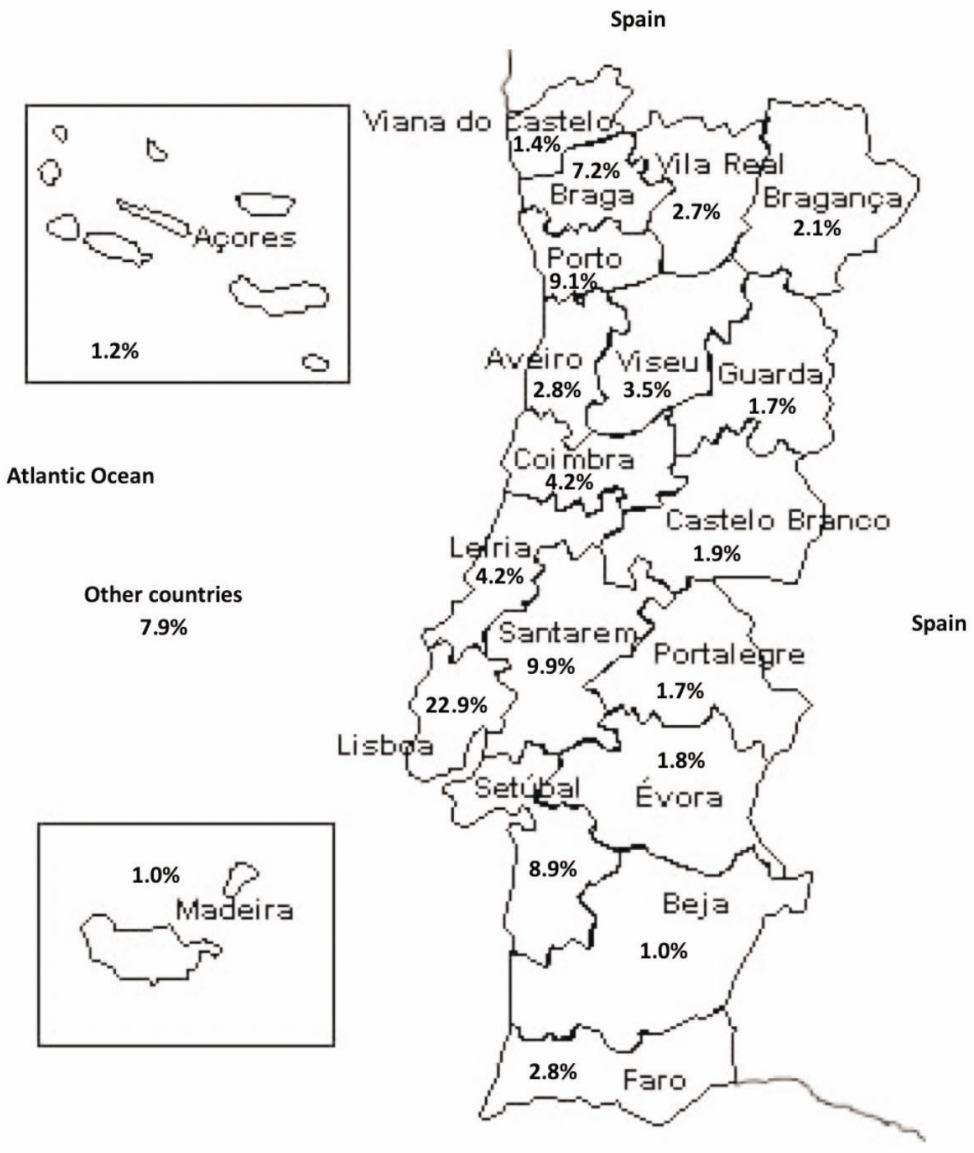

Atlantic Ocean

Figure 1 Cadets' district of birth (\%) - 2016

Source: Project "Cadets in Portuguese Military Academies in Portugal, 2016."

\section{Geographical origins}

Concerning geographical origin (place of birth), the majority of cadets come from the Lisbon district (22.9\%), then followed by Santarém (9.9\%); Porto (9.1\%), Setúbal $(8.9 \%)$ and foreign countries $(7.9 \%)^{3}$ (figure 1$)$.

3 This number includes cadets from African Portuguese speaking countries, and cadets born in different European countries as a result of the Portuguese emigration and the immigration to Portugal from Central and Eastern European countries after the end of the Cold War. 
This is not a surprising result if we consider that Lisbon and Setúbal are districts that also concentrate a high percentage of the Portuguese population and where the military academies are located. Since there is available data on this variable from the early decades of the $20^{\text {th }}$ century, it is possible to look at the evolution in geographical representation of cadets and inquire about its social and political meaning.

A similar pattern of dominant urban origins had been identified by Carrilho in her historical study ${ }^{4}$ covering the period 1926-1980 (Carrilho, 1982: 1158). Carrilho concluded that cadets from the Military Academy and Navy School who joined the academies throughout this period were mostly born in urban areas, especially in Lisbon. However, the concentration of cadets from the Lisbon region was much higher than it is at present: they were $43.6 \%$ of those who enrolled in the Military Academy in 1926, 43.7\% in 1930 and 40.6\% in 1962. This trend was even more relevant to the Navy School, which had $50 \%$ of Lisbon born cadets in 1950 and $58.1 \%$ in 1961. This concentration decreased significantly to around 30\% between 1976 and 1982, the decade after the restoration of democracy in the country.

Data from the study conducted in 2011 (Carreiras et al., 2011:45) confirmed this tendency, showing that $28.8 \%$ of the cadets were born in the Lisbon district; $12.0 \%$ in foreign country; $6.7 \%$ in Setúbal and 6.6\% in Santarém. In 2016, we identify a further reduction of the Lisbon district's contribution to $22.9 \%$, while Santarém and Setúbal increased respectively to $9.9 \%$ and $8.9 \%$ and Porto contributed with $9.1 \%$ of the cadets. In what regards "foreign countries," data points to a reduction: from $12 \%$ average in the period $1989-2010$ to $7.9 \%$ in 2016 .

Although there is still a prevalence of the littoral areas and an unbalanced situation concerning the overall territorial distribution, there is thus a clear decrease of the regional and urban concentration and a more diverse pattern of regional representation.

To what extent does the geographical representation differ by service academy?

Table 2 shows that while Lisbon is the district that supplies the higher percentages of cadets to all academies, the second district is different for each of them; Setúbal occupies the second position for Navy School cadets (18.8\%); Braga for Army (10.8\%), Santarém for Air Force cadets (10.0\%), and Porto to the GNR (12\%).

\section{Gender composition}

The presence of women in the armed forces, namely within the officer corps, has been considered one of the most sensitive indicators of both the level of civil-military convergence and of gender equality in the armed forces (Carreiras, 2018).

The participation of women in the Portuguese Armed Forces, with a full military status and in peacetime, is one of the most important transformations that took

4 The research focused on officers that finished the Military Academy and Navy School from 1900-1979, because the Air Force Academy was created only in the year of 1978.

SOCIOLOGIA, PROBLEMAS E PRÁTICAS, n.ํ9 93, 2020, pp. 9-29. DOI: 10.7458/SPP20209314043 
Table 2

Cadets' district of birth by academy

\begin{tabular}{|c|c|c|c|c|c|c|c|c|c|c|}
\hline \multirow{3}{*}{ District } & \multicolumn{10}{|c|}{ Academies } \\
\hline & \multicolumn{2}{|c|}{ Navy } & \multicolumn{2}{|c|}{ Army } & \multicolumn{2}{|c|}{ Air Force } & \multicolumn{2}{|c|}{ GNR } & \multicolumn{2}{|c|}{ Total } \\
\hline & $\mathrm{N}$ & $\%$ & $\mathrm{~N}$ & $\%$ & $\mathrm{~N}$ & $\%$ & $\mathrm{~N}$ & $\%$ & $\mathrm{~N}$ & $\%$ \\
\hline Aveiro & 1 & 0.5 & 9 & 3.2 & 3 & 2.1 & 9 & 5.4 & 22 & 2.8 \\
\hline Beja & 4 & 2.1 & 3 & 1.1 & 1 & 0.7 & - & 0.0 & 8 & 1.0 \\
\hline Braga & 9 & 4.7 & 30 & 10.8 & 6 & 4.3 & 11 & 6.6 & 56 & 7.2 \\
\hline Bragança & 1 & 0.5 & 9 & 3.2 & 2 & 1.4 & 4 & 2.4 & 16 & 2.1 \\
\hline Castelo Branco & 4 & 2.1 & 5 & 1.8 & 3 & 2.1 & 3 & 1.8 & 15 & 1.9 \\
\hline Coimbra & 11 & 5.7 & 9 & 3.2 & 6 & 4.3 & 7 & 4.2 & 33 & 4.2 \\
\hline Évora & 3 & 1.6 & 4 & 1.4 & - & 0.0 & 7 & 4.2 & 14 & 1.8 \\
\hline Faro & 5 & 2.6 & 10 & 3.6 & 4 & 2.9 & 3 & 1.8 & 22 & 2.8 \\
\hline Guarda & - & 0.0 & 10 & 3.6 & - & 0.0 & 3 & 1.8 & 13 & 1.7 \\
\hline Leiria & 7 & 3.6 & 12 & 4.3 & 9 & 6.4 & 5 & 3.0 & 33 & 4.2 \\
\hline Lisboa & 48 & 25.0 & 52 & 18.6 & 43 & 30.7 & 35 & 21.1 & 178 & 22.9 \\
\hline Portalegre & 5 & 2.6 & 4 & 1.4 & - & 0.0 & 4 & 2.4 & 13 & 1.7 \\
\hline Porto & 11 & 5.7 & 28 & 10.0 & 12 & 8.6 & 20 & 12.0 & 71 & 9.1 \\
\hline Santarém & 16 & 8.3 & 29 & 10.4 & 14 & 10.0 & 18 & 10.8 & 77 & 9.9 \\
\hline Setúbal & 36 & 18.8 & 12 & 4.3 & 13 & 9.3 & 8 & 4.8 & 69 & 8.9 \\
\hline Viana do Castelo & 1 & 0.5 & 3 & 1.1 & 3 & 2.1 & 4 & 2.4 & 11 & 1.4 \\
\hline Vila Real & 2 & 1.0 & 11 & 3.9 & 1 & 0.7 & 7 & 4.2 & 21 & 2.7 \\
\hline Viseu & 4 & 2.1 & 14 & 5.0 & 3 & 2.1 & 6 & 3.6 & 27 & 3.5 \\
\hline RA Madeira & 2 & 1.0 & 5 & 1.8 & 1 & 0.7 & - & 0.0 & 8 & 1.0 \\
\hline RA Açores & 1 & 0.5 & 1 & 0.4 & 3 & 2.1 & 4 & 2.4 & 9 & 1.2 \\
\hline Other districts & 21 & 10.9 & 19 & 6.8 & 13 & 9.3 & 8 & 4.8 & 61 & 7.9 \\
\hline Total & 192 & 100 & 279 & 100 & 140 & 100 & 166 & 100 & 777 & 100 \\
\hline
\end{tabular}

Source: Project "Cadets in Portuguese military academies in Portugal, 2016."

place in the post-Cold War era. Global numbers and representation levels grew rather rapidly from 1988, the year when women started to join, until 2010, and all formal restrictions were lifted during this period. Even if, as in other countries, integration patterns have highlighted a diversity of persistent obstacles and difficulties (Carreiras, 1997, 2006), the routinization of women's presence in the military was followed by growing public and institutional acceptance.

With regard to military academies, the progress in numerical representation has been extremely significant. Data regarding the period 1989-2011 showed that women made up an average of $6.9 \%$ of cadets (Carreiras et al., 2011). Even if it is not possible to directly compare the average figure for that period with a single observation in 2016, it is striking that female representation rose to $14.7 \%$ (table 3 ).

When geographical origin (place of birth) is cross-checked with gender, the regional distribution tends to be similar for men and women, with two exceptions: in the capital (Lisbon district) women's recruitment figures are significantly higher than those of men: almost $30 \%$ of women were born in Lisbon against $21.7 \%$ of men; in two other important districts - Porto and Coimbra - the opposite happens, with men's recruitment rates being considerably higher than women's (in Porto $9.8 \%$ versus $5.3 \%$ and in Coimbra $4.5 \%$ versus $2.6 \%$ ). 


\begin{tabular}{l|c|c|c|r|r|r}
\hline & \multicolumn{2}{|c|}{ Men } & \multicolumn{2}{c|}{ Women } & \multicolumn{2}{c}{ Total } \\
\cline { 2 - 6 } & $\mathrm{N}$ & $\%$ & $\mathrm{~N}$ & $\%$ & $\mathrm{~N}$ & $\%$ \\
\hline Navy School & 150 & 78.1 & 42 & 21.9 & 192 & 100.0 \\
Military Academy - Army & 252 & 90.3 & 27 & 9.7 & 279 & 100.0 \\
Military Academy - GNR & 145 & 87.3 & 21 & 12.7 & 166 & 100.0 \\
Air Force Academy & 116 & 82.9 & 24 & 17.1 & 140 & 100.0 \\
Total & 663 & 85.3 & 114 & 14.7 & 777 & 100.0 \\
\hline
\end{tabular}

Source: Project "Cadets in Portuguese military academies in Portugal, 2016."

Table 3 shows relevant differences in terms of service: the Navy School has the highest percentage of female cadets $(21.9 \%)$, followed by the Air Force $(17.1 \%)$, the GNR (12.7\%) and the Army (9.7\%). These figures are higher than the actual percentage of female officers in each of the three services, since around 3500 women represented $11 \%$ of the total active duty personnel in 2017 (Navy 8.4\%, Army 9.5\%, Air Force 13.4\%, GNR 6\%).

If we were to observe low attrition levels in the future, representation of women in the officer corps is expected to grow, especially in the Navy, where the percentage of female cadets nearly doubles that of female active duty officers.

Another comparison to make is with the results obtained in the international survey conducted by Bessa among Gendarmerie cadets in other European countries in 2009 (Bessa, 2015: 283). At that time, the Guarda Nacional Republicana (Portugal) had 14.5\% female cadets, the Guardia Civil (Spain) had $7.1 \%$, the Koninklijke Marechaussee (Nederland) $53.3 \%{ }^{5}$ and the Gendarmerie Nationale (France) 32.2\%.

These are strikingly different situations that reflect varying structural, policy and contextual conditions for which analysis is out of the scope of this article. For our purposes, the one aspect worth highlighting is the slight decrease in the percentage of GNR female cadets from $14.5 \%$ in 2009 to $12.7 \%$ in 2016.

\section{Social origins}

Concerning the officer corps' social origins, one important pattern that has been amply explored in the literature is self-recruitment, that is, the weight of those cadets whose fathers have or had a military profession. Our results show that while a large majority comes from other social backgrounds (83.4\%), still $16.6 \%$ of cadets come from a military family. If both military and police forces' origins are considered, results show that $26.4 \%$ of the cadets come either from a military or a police family. While gender differences are negligible with regard to police origins $(10.5 \%$ for female cadets and $9.7 \%$ for male cadets) these become noticeable in the case of military

5 The cadets from Koninklijke Marechaussee were only 15 (seven males and eight females) which is why there is this high percentage of female cadets. 


\begin{tabular}{l|c|c|c|r|r|r}
\hline & \multicolumn{2}{|c|}{ Military origins } & \multicolumn{2}{c|}{ Police origins } & \multicolumn{2}{c}{ Military or police origins } \\
\cline { 2 - 6 } & $\mathrm{N}$ & $\%$ & $\mathrm{~N}$ & $\%$ & $\mathrm{~N}$ & $\%$ \\
\hline Male cadets & 102 & 15.4 & 64 & 9.7 & 166 & 25.0 \\
Female cadets & 27 & 23.7 & 12 & 10.5 & 39 & 34.0 \\
Total (all cadets) & 129 & 16.6 & 76 & 9.8 & 205 & 26.4 \\
\hline
\end{tabular}

Source: Project "Cadets in Portuguese military academies in Portugal, 2016."

origins, where there is a significantly higher percentage of women cadets $(23.7 \%)$ than of male cadets $(15.4 \%$ ) (table 4 ). Overall, $34 \%$ of female cadets come from military or police backgrounds, for only $25 \%$ of male cadets.

An historical comparison shows interesting trends in this respect. In Carrilho's study (1982: 1159) it was found that 59.3\% of the cadets from the Military Academy that were born in the 1900-1910 decade came from a military background, a percentage that dramatically decreased to an average of $17.7 \%$ for cadets born in the period of 1950-1959. For the Navy School in the same period figures were less relevant and so was the intensity and direction of change: $16.7 \%$ and $20.6 \%$ respectively. During the period 1976-1983 the percentage of self-recruitment increased again and reached levels around 30\% (Carrilho, 1994: 140). According to Carrilho, such an increase reflected both a certain reconciliation with the military profession on the part of military families, due to the end of the Colonial War, and a strategy of upwards mobility, considering that almost half of the cadets came from lower rank categories, namely non-commissioned officers (NCO's).

More recently, Carreiras et al. (2011:59) found that, regarding cadets who enrolled in military academies between 1984 and 2003, 15.5\% in average had a military father and $7.1 \%$ came from a police background, reaching a total figure of $22.6 \%$. While there was a decline in self-recruitment over time, from extremely high levels at the beginning of the $20^{\text {th }}$ century to a situation of apparent stabilization in recent decades, present data point to a slight increase, since cadets from military or police background represent now $26.4 \%$ of the total.

If we take a closer look at those who come from military families $(16.6 \%)$, results show that military fathers are mostly from the Army, which points to a greater propensity for Army personnel to have their sons and daughters pursue an officer's career (table 5).

In terms of rank, table 5 also shows that military family antecedents include not only a very relevant percentage of officers but also of NCO's, which underlines an upwards social mobility trend. This is particularly significant in the case of Navy cadets, since $65.8 \%$ of those who have a military or police background come from the $\mathrm{NCO}$ and enlisted categories. ${ }^{6}$

As far as cadets whose father is or was a member of police forces (9.8\%) (table 6), data regarding the father's force, show that the overwhelming majority comes from the GNR, with the exception of cadets from the Navy whose police fathers come from 
Father in armed forces by cadets' academy, service and rank

\begin{tabular}{l|r|r|r|r|r|r|r|r|r|r}
\hline \multirow{2}{*}{ Cadets' academy } & \multicolumn{2}{|c|}{$\begin{array}{c}\text { Father in armed } \\
\text { forces }\end{array}$} & \multicolumn{3}{|c|}{ Military father's service (\%) } & \multicolumn{3}{c}{ Military father's rank (\%) } \\
\cline { 2 - 11 } & \multicolumn{1}{|c|}{ N } & $\%$ & Navy & Army & Air & Total & Officer & NCO & Enlisted & Total \\
\hline Navy School & 38 & 29.5 & 36.8 & 52.6 & 10.5 & 100.0 & 34.2 & 44.7 & 21.1 & 100.0 \\
Military Academy - Army & 45 & 34.9 & 17.8 & 57.8 & 24.4 & 100.0 & 51.1 & 44.4 & 4.4 & 100.0 \\
Military Academy - GNR & 16 & 12.4 & 25.0 & 56.3 & 18.8 & 100.0 & 43.8 & 37.5 & 18.8 & 100.0 \\
Air Force Academy & 30 & 23.3 & 30.0 & 36.7 & 33.3 & 100.0 & 50.0 & 43.3 & 6.7 & 100.0 \\
Total (all cadets) & 129 & 16.6 & 27.1 & 51.2 & 21.7 & 100.0 & 45.0 & 43.4 & 11.6 & 100.0 \\
\hline
\end{tabular}

Source: Project "Cadets in Portuguese military academies in Portugal, 2016."

\begin{tabular}{|c|c|c|c|c|c|c|c|c|c|c|}
\hline \multirow{2}{*}{ Cadets' academy } & \multicolumn{2}{|c|}{$\begin{array}{l}\text { Father in police } \\
\text { forces }\end{array}$} & \multicolumn{4}{|c|}{ Police force (\%) } & \multicolumn{4}{|c|}{ Rank (\%) } \\
\hline & $\mathrm{N}$ & $\%$ & GNR & PSP & PJ & Total & Officer & $\mathrm{NCO}$ & Enlisted & Total \\
\hline Navy School & 12 & 15.8 & 50.0 & 50.0 & - & 100.0 & 25.4 & 41.7 & 33.3 & 100.0 \\
\hline Military Academy - Army & 16 & 21.1 & 81.3 & 18.8 & - & 100.0 & 12.5 & 43.8 & 43.8 & 100.0 \\
\hline Military Academy — GNR & 39 & 51.3 & 76.9 & 20.5 & 2.6 & 100.0 & 5.1 & 30.8 & 64.1 & 100.0 \\
\hline Air Force Academy & 9 & 11.8 & 55.6 & 44.4 & - & 100.0 & 22.2 & 22.2 & 55.6 & 100.0 \\
\hline Total (all cadets) & 76 & 9.8 & 71.1 & 27.6 & 1.3 & 100.0 & 11.2 & 34.2 & 53.9 & 100.0 \\
\hline
\end{tabular}

Source: Project "Cadets in Portuguese military academies in Portugal, 2016."

GNR and PSP ( $50 \%$ each security force). Here, the upwards-social mobility pattern is highly emphasized if compared to military family cadets, since there is a much higher percentage with fathers coming from lower ranks (NCO and enlisted).

In sum, beyond historical variation, which has to be explained resorting to a diversity of social and political variables (where the 13 year-long Colonial War, led between 1961 and 1974, is paramount), self-recruitment seems to have stabilized at levels that, while being very relevant, point to a non-closure pattern, with the social origins of armed forces cadets are far from reproducing a "military caste," as has been the case in other countries (Carrilho, 1982: 1159; Castro, 1994).

But looking at self-recruitment patterns is only one aspect of the whole question of social origins. From which occupational groups are cadets being recruited? How representative and diverse is their social class background?

Results show that cadets come from a variety of social backgrounds, but also that the social recruitment basis seems to have shrunk in recent decades. While a plural recruitment pattern confirms most of previous research, there are now some interesting

6 Due to the specificity of its tasks, the Navy has a permanent board for enlisted personnel. The Army and Air Force have no such board and rely on short-term contract soldiers for the enlisted category. 


\begin{tabular}{|c|c|c|c|c|c|c|c|c|c|c|}
\hline \multirow[b]{2}{*}{ Social class* } & \multicolumn{2}{|c|}{ Navy } & \multicolumn{2}{|c|}{ Army } & \multicolumn{2}{|c|}{ Air Force } & \multicolumn{2}{|c|}{ GNR } & \multicolumn{2}{|c|}{ Total } \\
\hline & $\mathrm{N}$ & $\%$ & $\mathrm{~N}$ & $\%$ & $\mathrm{~N}$ & $\%$ & $\mathrm{~N}$ & $\%$ & $\mathrm{~N}$ & $\%$ \\
\hline Entrepreneurs and executives & 46 & 24.2 & 81 & 29.5 & 41 & 30.1 & 35 & 21.2 & 203 & 26.5 \\
\hline Professionals and managers & 78 & 41.1 & 86 & 31.3 & 50 & 36.8 & 54 & 32.7 & 268 & 35.0 \\
\hline Self-employed & 5 & 2.6 & 11 & 4.0 & 3 & 2.2 & 6 & 3.6 & 25 & 3.3 \\
\hline Pluriactive self-employment & 16 & 8.4 & 24 & 8.7 & 11 & 8.1 & 18 & 10.9 & 69 & 9.0 \\
\hline Routine employees & 24 & 12.6 & 40 & 14.5 & 18 & 13.2 & 27 & 16.4 & 109 & 14.2 \\
\hline Industrial workers & 5 & 2.6 & 17 & 6.2 & 4 & 2.9 & 4 & 2.4 & 30 & 3.9 \\
\hline Pluriactive routine employees & 16 & 8.4 & 16 & 5.8 & 9 & 6.6 & 21 & 12.7 & 62 & 8.1 \\
\hline Total & 190 & 100.0 & 275 & 100.0 & 136 & 100.0 & 165 & 100.0 & 766 & 100.0 \\
\hline
\end{tabular}

${ }^{*}$ ACM typology updated by Mauritti et al. (2016).

Source: Project "Cadets in Portuguese military academies in Portugal, 2016."

inflexions, since two different classes stand out: entrepreneurs and executives $(31.2 \%)$ and professionals and managers (30.0\%), followed, already at a distance, by routine employees (14.7), pluriactive self-employed (10.2\%). Pluriactive employees (5.8\%), self-employed (4,2\%) and industrial workers (4.0\%) are the less represented groups (table 7).

The overall pattern and rank order of the different social classes show some variation by academy. While those two groups are the most representative for all cadets, there is a slight over and under representation of these groups in different academies. The Navy is the branch with the highest percentage of cadets coming from the most educationally qualified sectors of professionals and managers $(41.1 \%)$, Air Force cadets have the highest percentage of entrepreneurs and executives (36.8\%) followed by Army cadets (29.5\%). There is thus a diverse social class origin, but with a significant weight of upper and middle classes.

It is not easy to compare this portrait with findings from previous decades, because of the different data sources (survey versus academic register's data) and inconsistent socio-economic classifications. However, it is possible to have a broad overview of major trends. With regard to cadets that were trained between 1984 and 2003 (Carreiras et al., 2011); there seems to be now a reinforcement of the more qualified and affluent sectors of the middle classes and a decrease in industrial and less qualified workers. Besides a similar self-recruitment level, the 2011 study had shown that there was a more evenly distributed origin throughout the various occupational groups, with routine employees or industrial workers acquiring then more relevance than at present.

A more complete picture of the diversity of cadet's social origins is achieved if we also take gender into consideration. Using a multiple correspondence analysis (MCA) (Carvalho, 2017), we obtained a representation of the most relevant associations between social classes, cadets' academy, and gender categories (figure 2). A social class classification with five categories was used in this analysis (instead of the seven categories previously presented) to avoid residual categories. 


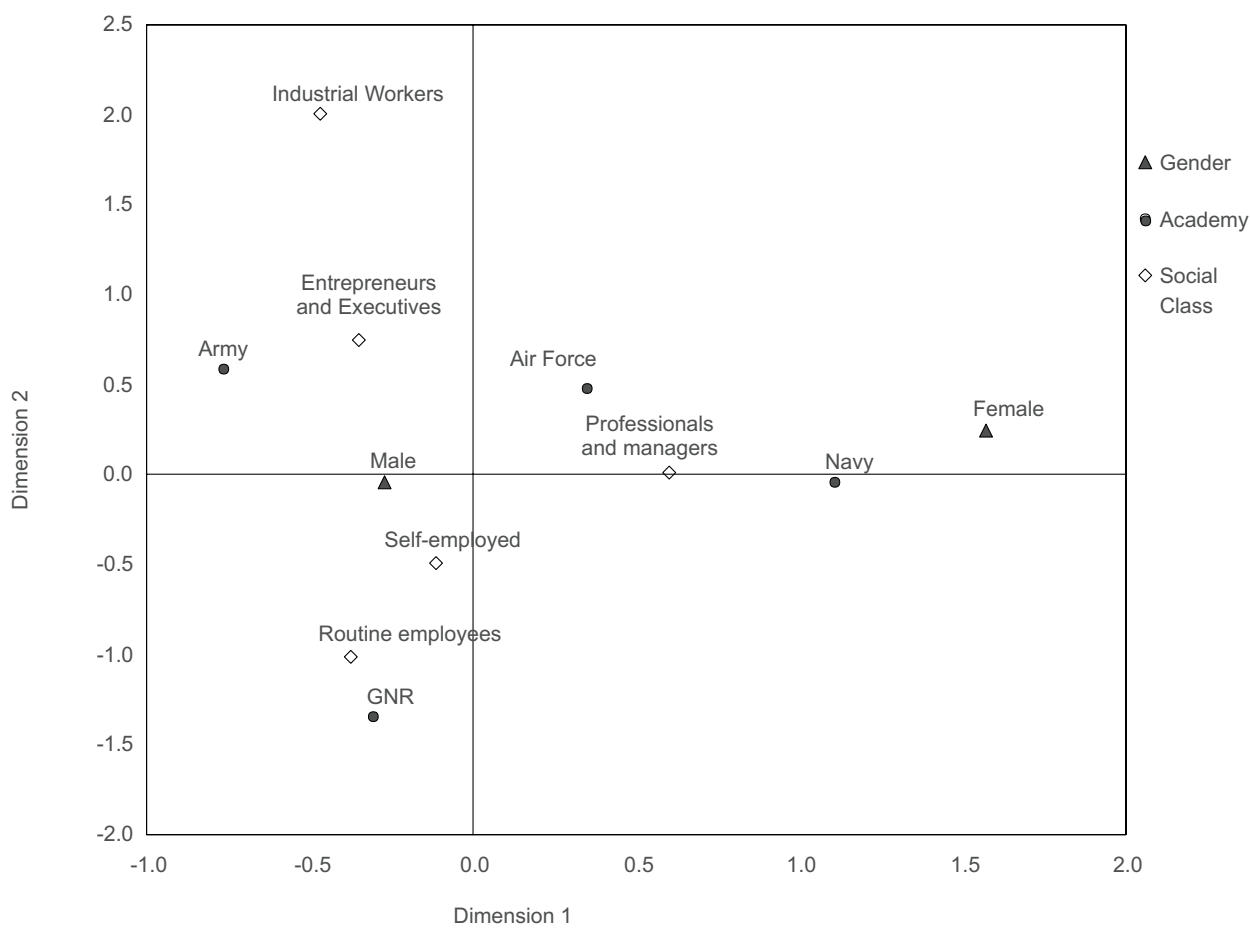

Figure 2 Cadets' academy, social class and gender (multiple correspondence analysis) Source: Project "Cadets in Portuguese Military Academies in Portugal, 2016."

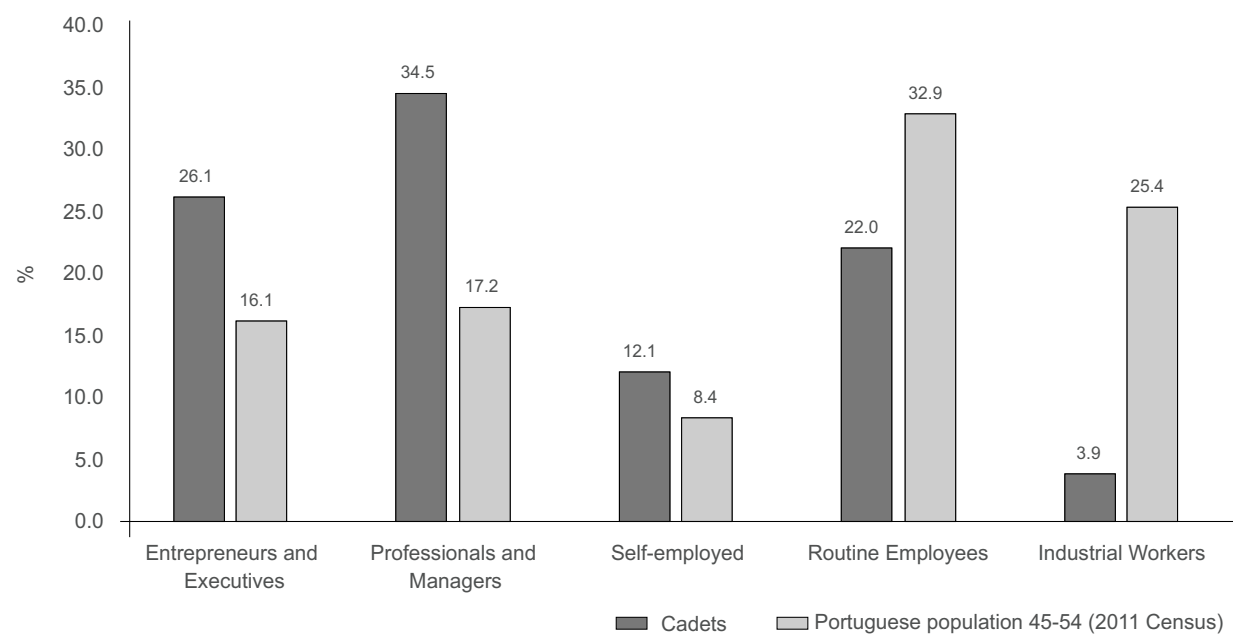

Figure 3 Cadets and Portuguese population (45-54 years) social classes (\%)

Source: Project "Cadets in Portuguese Military Academies in Portugal, 2016."

SOCIOLOGIA, PROBLEMAS E PRÁTICAS, n.․ 93, 2020, pp. 9-29. DOI: 10.7458/SPP20209314043 
Figure 2 confirms the existence of different patterns of social recruitment, namely by showing a clear association between professionals and managers with Air Force and Navy cadets, or between routine employees with GNR.

The MCA also revealed how the cadets' gender is associated with their social origins and the academies they attend. Considering only dimension 1 (the dimension where gender had a high discrimination measure), we observe that female cadets are mainly associated with the Navy, followed by Air Force, and are also associated with professionals and managers as their family social origins. This association between professionals and managers and female cadets is particularly relevant because it reveals that female cadets' families tend to have high levels of cultural and educational capital. Turning our attention to the male cadets (located at the left side of dimension 1), MCA shows the existence of a privileged association between this category and the social classes characterized by lower educational capital.

Finally, another important question was raised in our analysis: how do cadets' social origins compare with the Portuguese population as a whole? With the aim to answer this question we used data from the Portuguese Census of 2011, which is the last census data available. Given that cadets' social origins were analyzed using information from their parents, the social classes of individuals between 45 and 54 years-old were used as a reference for the Portuguese population (figure 3). The same strategy has been used in previous research about university students' social origins (Mauritti, 2003; Mauritti and Martins, 2009).

The main conclusion is that the social pattern of cadet's origins is much different from the social distribution of the Portuguese population, with around $60 \%$ of cadets coming from the social classes with higher economic, educational and cultural capitals - entrepreneurs and executives and professionals and managers. These two categories are clearly over-represented, with almost the double percentage value in comparison with similar categories in the Portuguese population, revealing that in Portugal military academies have presently a rather narrow social recruitment base. However, this strong social reproduction must be carefully interpreted, since the weight of the other social categories is not at all insignificant (around $40 \%$ ). This means that we are facing a double recruitment pattern (Mauritti and Martins, 2009: 86) where logics of social reproduction coexists with social mobility processes. It is important to mention that an identical pattern of recruitment can be in general observed in the high education systems, where the over-representation of the above-mentioned categories is also present with very similar values (Mauritti, 2003; Mauritti and Martins, 2009).

\section{Conclusion}

In this article we revisited the question of the social origins of the officer corps in the light of past and present theoretical discussions in the field of military studies, and developed a sociological portrait of the future Portuguese military elites. The data used was drawn from a major survey of the universe of cadets in the three service 
academies of the Portuguese Armed Forces, conducted in 2016. Being the product of a collaborative research framework involving the Military University Institute (IUM), the National Republican Guard (GNR) and the Centre for Research and Studies in Sociology (Cies_Iscte), this project represents an important effort at strengthening institutional cooperation and research outreach between civil and military spheres.

The article addressed different dimensions of the sociological characterization of the cadets, such as geographical origins, gender distribution, self-recruitment and social origins. When possible, current data was compared to results of previous studies to allow for the identification of change and continuity.

The research results highlight a variety of patterns and trends.

From the point of view of geographical origins, there is, as in the past, a predominance of the Lisbon district followed at a distance by a few others: Setúbal, Santarém, Porto and Braga, depending on the academy. While this pattern mirrors the strong presence of the Portuguese population in those littoral areas, the concentration pattern is much less relevant than in the past, with the current portrait showing a more balanced territorial distribution across the country.

With regard to gender, women are still a minority among cadets. However, not only are they overrepresented in academies if compared to the national average in each service, but the ceiling of token representation (15\%) has already been surpassed in one of them, the Naval School. If this trend consolidates and expands, it will possibly impact the gender power structure and overall equality in the Portuguese Armed Forces. Relative numbers are only one dimension of equality and assuring representation does not automatically translate into greater integration levels. However, not being a sufficient condition, numbers are a necessary condition to build a more balanced force.

As for social origins, results show important changes in the social composition of the Portuguese officer corps. The different methodological procedures for data collection (self-administered survey versus administrative records) and classification (different occupational group categories) between this and previous studies does not allow for easy comparisons and advises for caution in the interpretation of data. However, the present results point to a growing weight of the more educationally qualified and affluent sectors of society in the recruitment pattern of cadets.

Furthermore, through a multiple correspondence analysis, we confirmed the existence of different patterns of social recruitment between the academies, represented namely in the clear association between Air Force cadets and professionals and managers, and between GNR and routine employees. Female cadets are mainly associated with the Navy, followed by Air Force and they are also associated with professional and managers, which means that they are coming from families with high levels of cultural and educational capital. Male cadets are associated with classes with lower educational capital.

When compared with Portuguese society, cadets' social origins reveal a pattern of recruitment similar to that of university students, characterized by a clear over-representation of the social classes with higher economic, educational and 
cultural capitals - entrepreneurs and executives and professionals and managers. As other classe provenience is not insignificant (including self-recruitment), we conclude that there is a double recruitment pattern where a logic of social reproduction coexists with social mobility processes. While this also reflects changes towards greater qualification levels among similar groups in the external labour market (families of university students) (Mauritti et al., 2016), it certainly raises important questions regarding the civilian-military convergence thesis. If cadets are coming from upper classes more than they used to, what kind of consequences will this entail in terms of both the identity and representativeness of the officer corps? While there are good reasons to discard simple deterministic explanations connecting social origin and attitude or behaviour patterns, it is important to monitor the extent to which this trend might impact the organization, its internal balances, and its relation to society.

In sum, there is a global pattern of diversification of recruitment of the officer corps that confirms its consolidation as largely congruent with societal trends from the point of view of structural features. However, there are asymmetries in terms of gender and social origins that may raise future concerns, not only with regard to the civil-military convergence trend but also with regard to the distance between ranks inside the armed forces and the possible strengthening of internal differences. While gender representation indicators in academies have been moving towards a greater balance, the concentration of social origins of cadets on more affluent classes reveals a segmentation tendency that will probably require efforts at the level of recruitment and retention of NCO and enlisted soldiers in order to avoid a growing social gap between the top and the bottom of the rank structure.

\section{References}

Abrahamsson, Bengt (1972), Military Professionalisation and Political Power, London, Sage Publications.

Bessa, Fernando (2015), Oficiais da Guarda Nacional Republicana. Uma Análise Sociológica, Porto, Editora Fronteira do Caos.

Boene, Bernard (1990), "How unique should the military be? A review of representative literature and outline of a synthetic formulation", Archives Européennes de Sociologie, 31 (1), pp. 3-59.

Caforio, Giuseppe (1998), The European Cadet. Professional Socialization in Military Academies, Baden-Baden, Nomos.

Caforio, Giuseppe (Ed.) (2007a), Cultural Differences between the Military and Parent Society in Democratic Countries, Amsterdam, Elsevier.

Caforio, Giuseppe (Ed.) (2007b), Social Sciences and the Military, an Interdisciplinary Overview, London, Routledge.

Carreiras, Helena, (1997), Mulheres nas Forças Armadas Portuguesas, Lisbon, Cosmos.

Carreiras, Helena (2006), Gender and the Military. Women in the Armed Forces of Western Democracies, London, Routledge. 
Carreiras, Helena (2018) “Desigualdades de género nas instituições militares: o caso português em perspetiva comparada", em António Firmino da Costa, Renato Miguel do Carmo e Patrícia Ávila (eds.), Desigualdades Sociais. Portugal e a Europa, Lisbon, Mundos Sociais.

Carreiras, Helena, et al. (2011), Projecto "As Forças Armadas Portuguesas após a Guerra Fria", relatório final, Lisbon, CIES, ISCTE-IUL.

Carrilho, Maria (1982), “Origens sociais do corpo de oficiais das Forças Armadas portuguesas ao longo do século XX", Análise Social, XVIII (72-73-74), pp. 1155-1164.

Carrilho, Maria (1994), Democracia e Defesa. Sociedade, Política e Forças Armadas em Portugal, Lisbon, Dom Quixote.

Carvalho, Helena (2017), Análise Multivariada de Dados Qualitativos. Utilização da Análise de Correspondências Múltiplas com o SPSS, Lisbon, Edições Sílabo.

Castro, Celso (1994), “A origem social dos militares: novos dados para uma antiga discussão", Novos Estudos CEBRAP, 37, pp. 225-231

Feaver, Peter, and Richard H. Kohn (Eds.) (2001), Soldiers and Civilians. The Civil-Military Gap and American National Security. Cambridge, MA, The MIT Press.

Finer, Samuel E. (1962), The Man on Horseback. The Role of the Military in Politics, London, Pall Mall.

Harries-Jenkins, Gwin (1990), “The concept of military professionalism”, Defence Analysis, 2, pp. 117-130.

Huntington, Samuel (1957), The Soldier and the State. The Theory and Politics of Civil-Military Relations, Cambridge, MA, Belknap Press.

Internal Security Law (2008), Law n. 53 of 29 August.

Janowitz, Morris (1960), The Professional Soldier, New York, Free Press.

Mauritti, Rosário (2003), "Caracterização e origens sociais”, in João Ferreira de Almeida et al., Diversidade na Universidade. Um Inquérito aos Estudantes de Licenciatura, Oeiras, Celta Editora, pp. 13-30.

Mauritti, Rosário, and Susana Martins (2009), “Higher education students: contexts and social origns" in António Firmino da Costa et al. (Eds.), Portugal in the European Context, vol. II: Knowledge and Society, Oeiras, Celta Editora, pp. 81-98.

Mauritti, Rosário, Susana da Cruz Martins, Nuno Nunes, Ana Lúcia Romão, e António Firmino da Costa (2016), "The social structure of European inequality: a multidimensional perspective", Sociologia, Problemas e Práticas, 81, pp. 75-93.

Moskos, Charles (1977), "From institution to occupation: trends in military organization", Armed Forces and Society, 4 (Fall), pp. 41-50.

Moskos, Charles (1985), “La nueva organización militar: institucional, ocupacional o plural?", in Rafael Bãnon and José Antonio Olmeda (Eds.), La Institución Militar en el Estado Contemporáneo, Madrid, Alianza Universidad, pp. 140-152.

Moskos, Charles (1986), "Institutional/occupational trends in the Armed Forces: an update", Armed Forces and Society, 12 (3), pp. 377-382.

Moskos, Charles, and Frank Wood (Eds.) (1988), The Military, More Than Just a Job?, Washington, DC, Pergamon-Brasseys.

Moskos, Charles, Jay Williams, and David R. Segal (Eds.) (2000), The Postmodern Military, Oxford, Oxford University Press. 
Schiff, Rebecca (2009), The Military and Domestic Politics. A Concordance Theory of Civil-Military Relations, New York, Routledge.

Segal, David R. (1986), "Measuring the institutional / occupational chance thesis", Armed Forces \& Society, 12 (13), pp. 377-382.

Shields, Patricia M. (2006), "Civil-military relations: changing frontiers", Public Administration Review, November-December, 66 (6) pp. 924-928.

Helena Carreiras. Iscte - Instituto Universitário de Lisboa, Centro de Investigação e Estudos de Sociologia (Cies_Iscte), Lisboa, Portugal.

E-mail: helena.carreiras@iscte-iul.pt

Fernando Bessa. Military University Institute, Centre for Research in Security and Defence (CISD), Lisboa, Portugal. E-mail: a15277@hotmail.com

Patrícia Ávila. Iscte - Instituto Universitário de Lisboa, Centro de Investigação e Estudos de Sociologia (Cies_Iscte), Lisboa, Portugal. E-mail: patricia.avila@iscte-iul.pt

Luís Malheiro. Military University Institute, Centre for Research in Security and Defence (CISD), Lisboa, Portugal. E-mail: malheiro86@hotmail.com

Receção: 06 de março de 2018 Aprovação: 21 de março de 2019 